\title{
Iridana languyi sp. nov., a new Liptenine lycaenid species from Liberia (Lepidoptera, Lycaenidae, Poritiinae, Liptenini)
}

\author{
SZABOLCS SÁFIÁN* \\ Hungarian Natural History Museum, Department of Zoology, \\ H-1088 Budapest, Baross utca 13, Hungary \\ E-mail:szsafian@gmail.com
}

\begin{abstract}
Capture of the first female in the Nimba Mountains, Liberia reveals new identity to an Iridana Aurivillius, 1920 species (Lepidoptera, Lycaenidae, Poritiinae), previously identified from the male as I. agneshorvathae Collins, Larsen \& Sáfián, 2008. The male and the matching female represent an undescribed species and is named as I. languyi sp. nov. The newly described species is known only from the upland forest zone of two mountainous areas in Liberia. With 27 figures.
\end{abstract}

Key words - genus Iridana, I. agneshorvathae-group, I. obscura-group, Liberian subregion, endemism

\section{INTRODUCTION}

Iridana Aurivillius, 1920 (type species: Iris incredibilis Staudinger, 1891) is a small, purely Afrotropical genus in the family Lycaenidae (subfamily Poritiinae, tribe: Liptenini). Most species are very rare or rarely encountered as adults tend to fly just below the canopy level or above the high canopy of tropical rainforest (LARSEN 2005, Sáfián pers. obs.). Only one species is known to occur in more open Brachystegia (miombo) woodland (GARDINER 2010). The caterpillars are obligately ant-associated and are found only on the bark of Crematogaster Lund, 1831 (Formicidae: Myrmicinae) ant infested trees, where they live in a self-sawn silk-chamber (SÁFIÁn \& Collins 2014). Probably because of these reasons, many species are extremely local, and their distribution is also restricted, and as a result, general knowledge on the genus and on most of the species is limited (LARSEN 2005, D'ABRERA 2009). For their rarity and obscure behaviour, it is not rare to discover new species in the genus; six species have been described from the Democratic Republic of Congo, Cameroon, Ghana and Liberia only in the last decade (Bouyer 2013, 2014, 2015a, 2015b, Collins \& SÁfián, 2014, SÁFián

* Volunteer Research Associate of the Lepidoptera Collection 
\& Collins 2014), and a taxonomic revision of the genus could probably reveal a few more. Currently, the genus counts 25 species with no subspecies recognized (see below).

In 2018 the author collected a male Iridana in the Wologizi Mountains in Liberia, which at first sight was recognized as I. agneshorvathae Collins, Larsen \& Sáfián, 2008 (COLLINS \& LARSEN 2008), previously known only from two specimens collected in Ghana (SÁfIÁN et al. 2012). The record was recently published as such, with the first female of $I$. agneshorvathae captured in Benin (SÁFIÁN \& COACHE 2020). The authors noted minor morphological differences, but from a single specimen, these differences could have represented individual variation across the geographic range. A capture of a female Iridana in the Nimba Mountains, Liberia, strongly resembling to the only known female of I. agneshorvathae provided new material for comparison. The initially recognised morphological differences between the Ghanaian and Liberian males were confirmed also in the opposite sex, which led the Liberian taxon to be recognised as a distinct and new species.

\section{MATERIALS AND METHODS}

Wing venation references follow the numeric of English system as described in MILLER (1970) and used by the authors widely in taxonomic work on butterflies (e.g., SÁFIÁn 2021, SÁfián et al. 2020, 2021).

To correctly position the new species, a check-list of all known taxa in the genus are compiled and presented using BOUYER (2013, 2014, 2015a, 2015b), Bouyer \& Ducarme (2015), Collins \& Larsen (2008), Collins \& Sáfián (2014), D'ABRERA (2009), SÁ FIÁn \& Collins (2014) with preliminary grouping based on morphological similarities and previous tentative groups established by BOUYER (2013, 2014, 2015) and Collins \& SÁFIÁN (2014).

Acronyms and abbreviations: ANHRT - African Natural History Research Trust, Leominster, UK; DRC - Democratic Republic of Congo; HNHM Hungarian Natural History Museum, Budapest, Hungary.

\section{RESULTS}

Ordo LEPIDOPTERA Linnaeus, 1758

Superfamily PAPILIONOIDEA Latreille, 1802

Family LYCAENIDAE Leach, 1815

Subfamily PORITIINAE Doherty, 1886

Tribe: LIPTENINI Röber, 1892

Genus Iridana Aurivillius 1921

Type species: Iris incredibilis Staudinger, [1891] 
Check-list

Iridana incredibilis-group

Iridana incredibilis (Staudinger, 1891)

Iridana rougeoti Stempffer, 1964

Iridana gabunica Stempffer, 1964

Iridana tororo Stempffer, 1964

Iridana euprepes-group

Iridana euprepes (Druce, 1905)

Iridana perdita-group

Iridana perdita (Kirby, 1890)

Iridana marina Talbot, 1935

Iridana bwamba Stempffer, 1964

Iridana katera Stempffer, 1964

Iridana kollariki Sáfián, 2014

Iridana obscura-group

Iridana obscura Stempffer, 1964

Iridana pseudobscura Bouyer, 2014

Iridana michaelgwynnei Collins \& Sáfián, 2014

Iridana unyoro-group

Iridana unyoro Stempffer, 1964

Iridana agneshorvathae-group

Iridana agneshorvathae Collins, Larsen \& Sáfián, 2008

Iridana languyi sp. nov.

Iridana hypocala-group

Iridana hypocala Eltringham, 1929

Iridana magnifica Hawker-Smith, 1933

Iridana jacksoni Stempffer, 1964

Iridana ducarmei Bouyer, 2013

Iridana noellae Bouyer, 2014

Iridana larseni Bouyer, 2015

Iridana nigeriana-group

Iridana nigeriana Stempffer, 1964

Iridana ghanana Stempffer, 1964 


\section{Incertae sedis}

Iridana exquisita (Grose-Smith, 1898)

Iridana stempfferi Bouyer, 2015

\section{Description of new species}

\section{Iridana languyi sp. nov.}

(Figures 2, 4, 6, 8, 9, 12, 17-18, 24)

Material - Holotype, female, LIBERIA, Nimba Mountains, East Nimba Nature Reserve, Cellcom Road 1155 m. 7³1’41.90”N, 8³1'39.81”W, 02.III.2021. Leg.: Sáfián, Sz., Languy, M. DNA sample code: LepAf24. Deposited in the HNHM. Paratype, male, LIBERIA, Lofa County, Wologizi Mountains, Belegizi Ridge and Summit, 8'7'27.24"N, 9'56'10.91"W, 1000-1086 m asl. 4-9.XI.2019. Leg.: Sáfián. Sz., Simonics, G. ANHRT: 2018.43. ANHRT unique number: ANHRTUK00058080. Deposited in ANHRT.

Description and diagnosis - The size and general appearance of both sexes of the new species are like those of Iridana agneshorvathae as described in Collins \& LARSEN (2008) and in SÁFIÁN \& COACHE (2020). However, they differ in the following six features. (1) Forewing outer margin of I. languyi sp. nov. in both sexes is distinctly more concave compared to that of of I. agneshorvathae, which is almost straight in the latter species (Figures 1-8). (2) Hindwing tornus is less drawn-out in both sexes of $I$. languyi sp. nov. compared to that of $I$. agneshorvathae (Figures 1-8). (3) In the fork of veins 1 and 2 of forewing upperside, the basal, black, possibly androconial pit is twice as long in I. languyi sp. nov. as in $I$. agneshorvathae (there is no sign of physical damage on the wing) (Figures 2324). (4) The typical Iridana pattern in the median of hindwing underside formed by silvery lines is distinctly finer in both sexes of $I$. languyi sp. nov. than in $I$. agneshorvathae, the width of the lines is twice as broad in certain sections of the female of $I$. agneshorvathae as in the new taxon (Figures 3, 4, 7, 8). (5) The light grey cell-closing discal spot on forewing underside in I. languyi sp. nov. is half the width of that in I. agneshorvathae in both sexes (Figures 3, 4, 7, 8). (6) Although their wingshape is different, in the fine silvery pattern on hindwing underside the new species resembles to members of the I. obscura species group (Collins \& SÁfIÁN 2014), namely I. michaelgwynnei and I. pseudobscura (Figures 12-14), including a rudimental version of the tear-shaped spot in the fork of veins 3 and 4 on hindwing underside, characteristic to this group as described in CoLlins $\&$ SÁfIÁN (2014) (Figures 17-22). In both sexes of I. agneshorvathae the silver area in the fork is clearly attached to the band (Figures 15-16). 


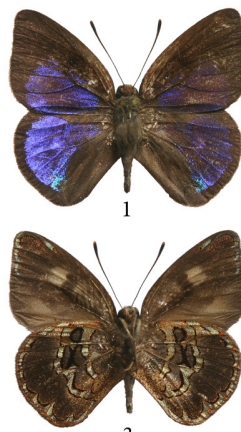

3
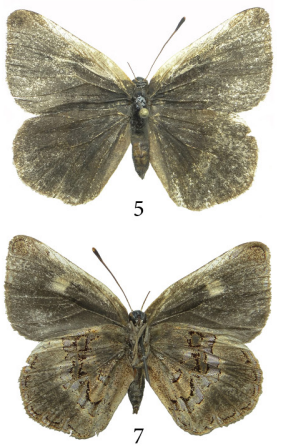
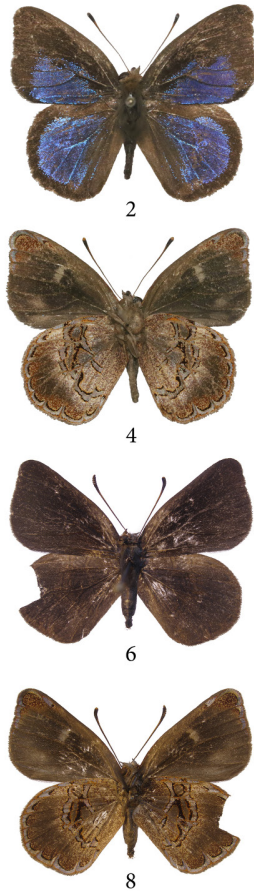

$10 \mathrm{~mm}$

Figures 1-8. Adults of Iridana species: 1 = Iridana agneshorvathae (holotype) upperside; $3=I$. agneshorvathae (holotype) underside; $2=I$. languyi sp. nov. male (paratype) upperside; $4=I$. languyi sp. nov. male (paratype) underside; $5=$ I. agneshorvathae female (Benin) upperside; 7 = I. agneshorvathae female (Benin) underside; $6=$ I. languyi sp. nov. female (holotype) upperside; $8=I$. languyi sp. nov. female (holotype) underside.
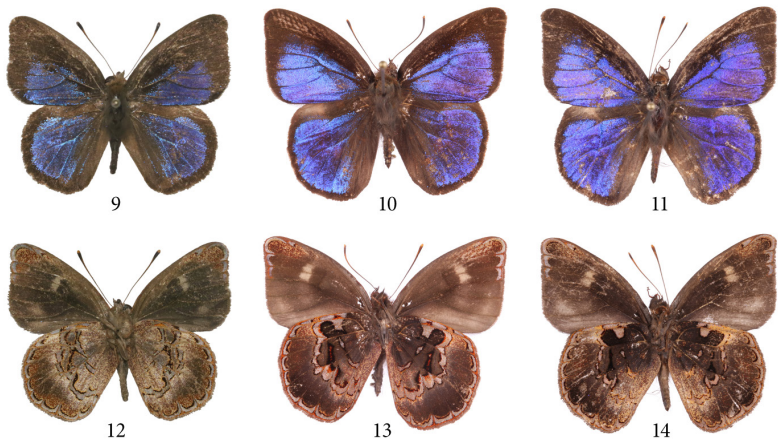

$10 \mathrm{~mm}$

Figures 9-14. Males: $9=$ Iridana languyi sp. nov. (paratype) upperside; $12=$ I. languyi sp. nov. (paratype) underside; $10=I$. pseudobscura (Mintom, Cameroon) upperside; $13=I$. pseudobscura (Mintom, Cameroon) underside; $11=I$. michaelgwynnei (holotype) upperside; $14=I$. michaelgwynnei (holotype) underside. 
Distribution and Bionomics - The species is known so far from two mountainous areas in Liberia, the Wologizi Mountains and the Nimba Mountains. In both localities a single specimen was captured in the upland forest zone between 1000-1200 $\mathrm{m}$ asl (Figure 27).

Etymology - The species is dedicated to Marc Languy, a Belgian senior conservationist and protected area management expert, who has been working to establish higher management standards in protected areas in the DRC, Kenya, Cameroon and elsewhere for many years.

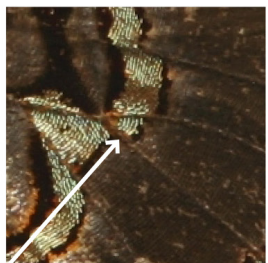

15

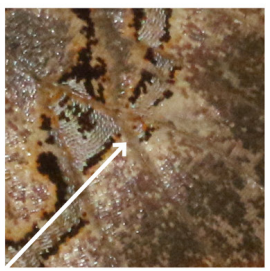

17

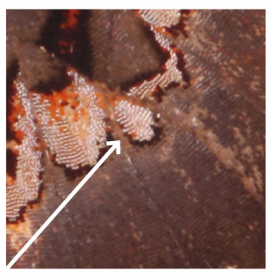

19

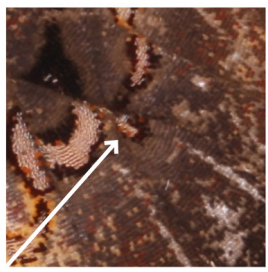

21

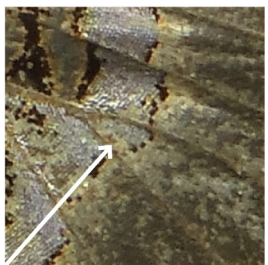

16

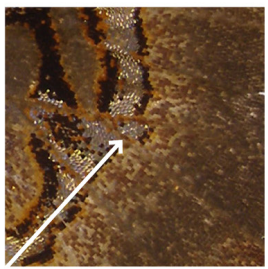

18

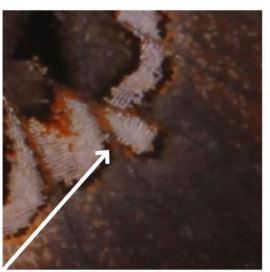

20

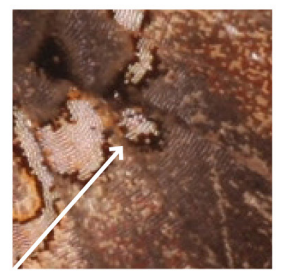

22

Figure 15-22. Magnified hindwing underside featuring the characteristic spot in the fork of veins 3 and 4 (indicated by arrow): 15 = Iridana agneshorvathae (holotype); $16=$ I. agneshorvathae (female, Benin); 17 = I. languyi sp. nov. (male paratype); 18 = I. languyi sp. nov. (holotype); $19=I$. pseudobscura (male, Cameroon); $20=I$. pseudobscura (female, Cameroon); $21=I$. michaelgwynnei holotype; $22=I$. michaelgwynnei (female paratype). 


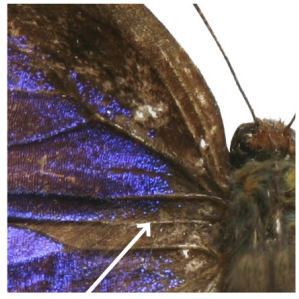

23

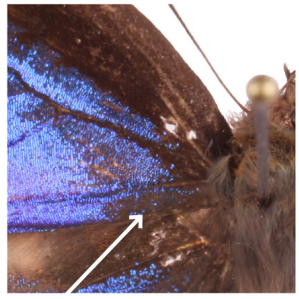

25

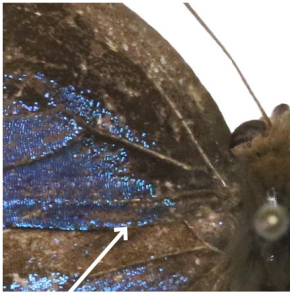

24

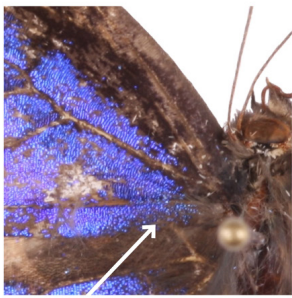

26

Figures 23-26. The basal, brown, potentially androconial spot on the dorsal forewing surface (indicated by arrow): 23 = Iridana agneshorvathae; $24=I$. languyi $25=I$. pseudobscura and $26=$ I. michaelgwynnei.

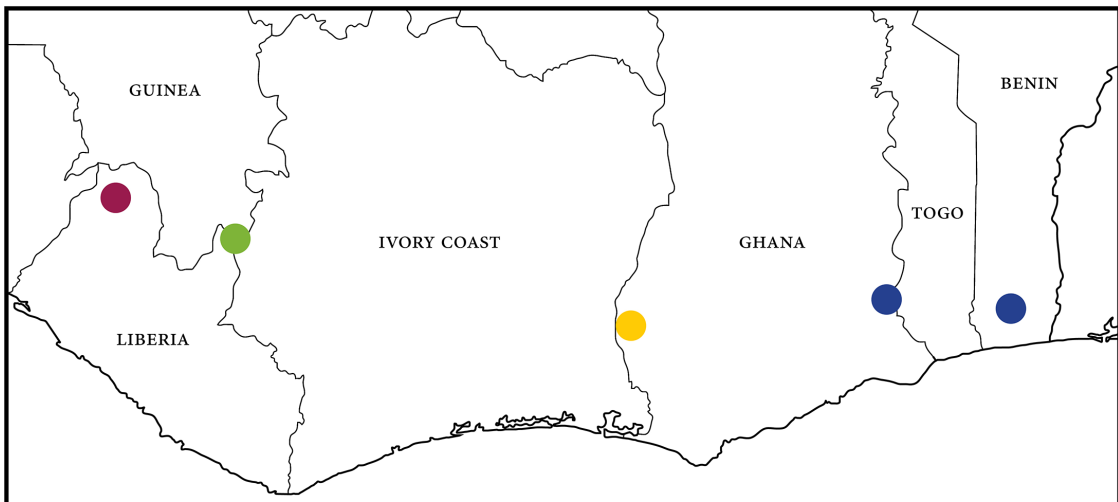

Iridana agneshorvathae type locality

- Iridana agneshorvathae new localities

Iridana languyi sp. nov. type locality

- Iridana languyi sp. nov. male paratype locality

$250 \mathrm{~km}$

Figure 27. Iridana languyi sp. nov. and I. agneshorvathae distribution records. 


\section{DISCUSSION}

Commentsforidentification - Both sexes of Iridana languyi sp. nov. are significantly smaller than any members of the I. obscura species group and the female has no iridescent blue scaling on the upperside similarly to that of $I$. agneshorvathae. This and the more rounded hindwing shape actually also set it closer to the latter species, hence the decision of the position of the species in the I. agneshorvathaegroup. Although the upperside's iridescent blue colour will probably also prove to be diagnostic, here it is not compared as iridescent blue reflections are very difficult to reproduce in high fidelity by photography and the specimens were photographed under different lighting circumstances. The holotype and the paratype specimens are not dissected as there are no diagnostic information known to be carried by genitalia (STEMPFFER 1968: 75; teste LARSEN 2005).

Biogeographical remarks - Beside the insufficient comparative material, the original misunderstanding of I. languyi sp. nov. is a result of the fact that the rate of endemism in Ghana subregion is rather low and the majority of Upper Guinean Forest Zone endemics that occur in Ghana has a rather broad distribution between the Dahomey Gap, Sierra Leone and the Forest Region of Guinea. Even species previously believed to be restricted to the Ghana subregion (LARSEN 2005) were recently found also in Liberia, more precisely in the Wologizi Mountains (e.g., Liptena seyboui Warren-Gash \& Larsen, 2003, Bebearia ashantina (Dudgeon, 1913)) (SÁFIÁN \& LORENC-BRUDECKa 2020, SÁfiÁn et al. 2020), where the holotype of $I$. languyi was also collected. The known localities (Figure 27) indicate that $I$. languyi sp. nov. is yet another Liberian subregion endemics, or a species narrowly endemic to the mountains of the Guinea Highlands as discussed in SÁFIÁN (2021). We also cannot rule out that the range of the two species could actually fully overlap or they could be parapatric, I. agneshorvathae being a lowland forest species, distributed across the Upper Guinean Forest Zone, with the strictly upland species I. languyi sp. nov. present only at higher altitudes.

Acknowledgements - The author is grateful to Renátó Molnár (Biatorbágy, Hungary) for editing the plates and map, and to Balázs Tóth (HNHM, Budapest) for photographing the paratype of I. languyi. Zsolt Bálint (HNHM, Budapest) has kindly reviewed the first draft of the description. The annotations of the reviewers are highly appreciated.

\section{REFERENCES}

Bouyer T. 2013: Description d'une nouvelle espèce d'Iridana Aurivillius, 1920 du Congo (R. D.) (Lepidoptera, Lycaenidae). - Entomologia Africana 18(1): 4-6. 
Bouyer T. 2014: Description de nouvelles espèces d'Iridana Aurivillius, 1920 (Lepidoptera, Lycaenidae). Etude sur les Lycaenidae: note ${ }^{\circ}$ 15. - Lambillionea 114(1): 70-73.

Bouyer T. 2015a: Description d'une nouvelle espèce d'Iridana Aurivillius, 1920 du Cameroun (Lepidoptera, Lycaenidae). Etude sur les Lycaenidae: note $n^{\circ}$ 17. - Entomologia Africana 20(1): 41-44.

Bouyer T. 2015b: Description de nouvelles espèces d'Iridana Aurivillius, 1920 (Lepidoptera, Lycaenidae). Etude sur les Lycaenidae: note n 19. - Entomologia Africana 20(2): 7-9.

Bouyer T. \& DUCAR ME R. 2015: Note sur les Iridana Aurivillius, 1920 (Lepidoptera, Lycaenidae). Etude sur les Lycaenidae: note $\mathrm{n}^{\circ}$ 18. - Lambillionea 115(1): 12-14.

Collins S. C. \& LARSEN T. B. 2008: Eighteen new species, five new subspecies, and interesting data on other African butterflies - Fourth ABRI Research Paper. - Metamorphosis 19(2): 41-114.

Collins S. C. \& SÁfián Sz. 2014: Notes on the Iridana obscura species group with the description of a new species from western Cameroon (Lycaenidae: Lipteninae: Epitolini). Metamorphosis 25: 141-146.

D'A BreRA B. 2009: Butterflies of the Afrotropical Region Part III Lycaenidae, Riodinidae. - Hill House Publishers, Melbourne \& London, pp 531-880.

GARDINER A. J. 2010: Additional butterfly records for Zambia and changes in the taxonomic status of a few species. - Metamorphosis 21(4): 142-155.

LARSEN T. 2005: Butterflies of West Africa. - Apollo Books, Svendborg, 595 pp + 135 colour plates.

Miller L. D. 1970: Nomenclature of wing veins and cells. - Journal of Research on the Lepidoptera 8: $37-48$.

SÁfiÁn Sz. 2021: The butterfly fauna (Lepidoptera: Papilionoidea) of Liberia. PhD thesis. University of Sopron, $260 \mathrm{pp}+101$ colour plates.

SÁfián Sz., BelCastro C., Bouireau P. \& Collins, S. C. 2020: New taxa of skipper butterflies (Lepidoptera, Hesperiidae) from tropical Africa. - Metamorphosis 31: 56-71.

SÁfiÁn Sz. \& CoACHE A. 2020: New data on the distribution of Iridana agneshorvathae Collins, Larsen \& Sáfián, 2008 with description of the previously unknown female (Lepidoptera, Lycaenidae, Poritiinae). - Faunitaxys 8(3): 1-3.

SÁfiÁn Sz. \& Collins S. C. 2014: A new Iridana Aurivillius, 1920 and a new Teratoneura Dudgeon, 1909 (Lepidoptera: Lycaenidae) from tropical Africa. - Metamorphosis 25: 90-96.

Sáfián Sz., Collins S. C., Warren-Gash H. \& Belcastro C. 2021: Description of five new species of Epitola sensu lato (Lepidoptera: Lycaenidae: Poritiinae) from West and Central Africa. - Zootaxa 4981(3): 554-576.

Sáfián Sz., KoÏvogui S., Simonics G. \& FlorczyK K. J. 2020: Butterfly diversity (Lepidoptera: Papilionoidea) in the Ziama Massif in Guinea and the adjacent Wonegizi and Wologizi Mountains in Liberia (West Africa): A transboundary conservation approach. - Metamorphosis 31(1): 104-128.

Sáfián Sz., Larsen T. B., Collins S. C., Csontos G \& Aduse-Poku K. 2012: Results of the butterfly and moth inventory in Ghana I. (Lepidoptera: Lycaenidae). - Folia Entomologica Hungarica 73: 53-75.

SÁFIÁN SZ. \& LORENC-BRUdECKA J. 2020: Unique genitalic structure in a West African lycaenid butterfly, Liptena seyboui Warren-Gash \& Larsen, 2003 (Lepidoptera, Lycaenidae, Poritiinae, Liptenini). - Metamorphosis 31: 4-6. 
STEMPFFER H. 1967. The genera of the African Lycaenidae (Lepidoptera: Rhoplaocera). - Bulletin of the British Museum (Natural History), Entomology Series, Supplement 10: 1-233.

\title{
Iridana languyi sp. nov., új zuzmászka faj Libériából (Lepidoptera, Lycaenidae, Poritiinae, Liptenini)
}

\author{
SÁfián Szabolcs \\ Magyar Természettudományi Múzeum, Állattár, H-1088 Budapest, Baross utca 13., Magyarország \\ E-mail:szsafian@gmail.com
}

\begin{abstract}
Összefoglalás - Az első begyűjtött nőstény egyed nyújtott elegendő információt a korábban I. agneshorvathae-ként leírt zuzmászka faj (Lepidoptera, Lycaenidae, Poritiinae) pontosabb meghatározásához. A hím és a szárnyak rajzolatában megegyező nőstény leíratlan fajnak bizonyult, amely I. languyi sp. nov. néven kerül közlésre. Az új faj kizárólag Libéria középhegységi erdőzónájából ismert. 27 ábrával.
\end{abstract}

Kulcsszavak - Iridana génusz, I. agneshorvathae fajcsoport, I. obscura fajcsoport, Libériai szubrégió, endemizmus

\section{ÁBRAMAGYARÁZATOK}

1-8. ábra. Iridana imágók: 1 = Iridana agneshorvathae (holotípus) felszín; $3=I$. agneshorvathae (holotípus) fonák; $2=I$. languyi sp. nov. hím (paratípus) felszín; $4=I$. languyi sp. nov. hím (paratípus) fonák; $5=I$. agneshorvathae nőstény (Benin) felszín; $7=I$. agneshorvathae nőstény (Benin) fonák; $6=$ I. languyi sp. nov. (holotípus) felszín; $8=I$. languyi sp. nov. (holotípus) fonák.

9-14. ábra. Iridana hímek: 9 = Iridana languyi sp. nov. (paratípus) felszín; $12=$ I. languyi sp. nov. (paratípus) fonák; $10=I$. pseudobscura (Mintom, Kamerun) felszín; $13=I$. pseudobscura (Mintom, Kamerun) fonák; $11=I$. michaelgwynnei (holotípus) felszín; $14=I$. michaelgwynnei (holotípus) fonák.

15-22. ábra. A hátulsó szárny fonákján kinagyítva a 3. és 4. erek tövében található jellegzetes foltrajzolat (nyíl jelzi): 15 = Iridana agneshorvathae (holotípus); 16 = I. agneshorvathae (nőstény, Benin); $17=$ I. languyi sp. nov. (hím paratípus); 18 = I. languyi sp. nov. (holotípus); $19=I$. pseudobscura (hím, Kamerun); $20=I$. pseudobscura (nőstény, Kamerun); $21=I$. michaelgwynnei (holotípus); $22=I$. michaelgwynnei (nőstény paratípus) $-\mathrm{H}$.

23-26. ábra. Az elülső szárnyfelszín tövében lévő barna, lehetséges androkoniális folt (nyíl jelzi): 23 = Iridana agneshorvathae (holotípus); $24=$ I. languyi sp. nov. (hím paratípus); $25=I$. pseudobscura (hím, Kamerun); $26=$ I. michaelgwynnei (hím, Kamerun).

27. ábra. Az Iridana languyi sp. nov. és az I. agneshorvathae előfordulási pontjai. 